\title{
PENGARUH PROSES POLITIK, SEBELUM SELAMA DAN SESUDAH PILPRES 2019 TERHADAP HARGA SAHAM
}

\author{
Arum Arupi Kusnindar ${ }^{1}$, Aditia Yudis Puspitasari² \\ ${ }^{1 \& 2}$ Universitas Muhammadiyah Pringsewu \\ arumkusnindar@gmail.com ${ }^{1},{\text { aditia@ } \text { umpri.ac.id }^{2}}^{2}$
}

\begin{abstract}
The capital market is a gateway for investment into a country, the greater of income investment is an indicator of the better economy country. There are many things that can affect stock price movements on the stock market, including the company's financial performance and other internal factors within the company, as well as external factors for companies, for example the political conditions of a country. This study aims to determine the movement of stock values before the April 2019 election, during the election process until after the election process. This research is a quantitative research with an event study approach before, during and after the event / event day. The analysis is done by calculating and comparing the abnormal return and normal return as well as the mean difference from the stock return during the event.
\end{abstract}

The results of this study indicate that there is no significant abnormal return during the observation period, namely 10 days before the event, at the time of the event and 10 days after the event and there is no difference in abnormal returns between the three periods of observation of political events in Indonesia, namely the election on April 17 2019, there was no difference. has a significant impact on share prices. The market has the belief that the election will run smoothly and smoothly and there will be no economic and political turmoil so that investors do not sell excessively. Investors tend to hold back / wait and see on economic and political conditions. This is shown by the index that remains stable, even if there is a negative trend within a few days it will be corrected positively again.

Keywords: Political Process, Stock Price, Abnormal Return, Stock Return

\section{PENDAHULUAN}

Pasar modal merupakan pintu gerbang investasi masuk ke dalam sebuah negara. Kinerja pasar modal juga menjadi acuan untuk menilai kinerja keuangan dan industri di sebuah negara sehingga keputusan melakukan investasi mempertimbangankan kinerja perusahaan yang tampak dalam pasar modal. Pasar modal juga membantu perusahaan mendapatkan dana untuk melakukan dan mengembangkan kegiatan bisnis. Dengan makin meningkatnya investasi serta meningkatnya kemampuan pendanaan perusahaan akan terbuka kesempatan kerja yang lebih banyak, meningkatkan pendapatan negara serta menjadi indikator makin baiknya perekonomian suatu negara.

Selama tahun 2018, Pasar modal Indonesia melalui Bursa Efek Indonesia menunjukan respon pasar yang positif dan optimis terhadap masa depan 
perekonomian Indonesia. Ditunjukan dengan rata-rata transaksi harian di BEI mencapai 387 ribu transaksi. Dari segi perusahaan tercatat, BEI berhasil memfasilitasi 57 perusahaan tercatat baru. Dari segi pengembangan investor, tercatat pertumbungan sebesar $44 \%$ dari 1.1 juta investor di tahun 2017 menjadi 1.6 juta investor pada tahun 2018 .

Pada kuartal pertama tahun 2019, terdapat pelemahan dan posisi konsolidasi, di tunjukan dari posisi IHSG pada $6.547,87$ pada 6 Februari dan turun ke posisi 6.366 pada 11 Maret namun naik kembali pada posisi $6.468,76$ pada 29 Maret. Investor cenderung memilih posisi wait and see terkait dengan akan diadakannya pemilu pada bulan April 2019 sedangkan sentiment global di pengaruhi oleh ketakutan munculnya resesi ekonomi yang di picu perang dagang antara Amerika dan Cina.

Indeks Harga Saham Gabungan (IHSG) pertama kali di terbitkan pada 1 April 1983 dengan tujuan sebagai indikator pergerakan harga saham perusahaan yang tercatat di bursa. IHSG menggunakan seluruh emiten yang tercatat sebagai komponen perhitungan indeks dengan metode rata-rata tertimbang berdasarkan nilai pasar (market value) Selain IHSG, terdapat beberapa jenis indeks lainnya antara lain; Indeks Sektoral, Indeks LQ 45, Jakarta Islamic Index, Indeks PEFINDO 25, Indeks KOMPAS, Indeks SRIKEHATI dan beberapa jenis Indeks lainnya. Penelitian ini menggunakan Indeks LQ45 karena indeks ini adalah gabungan dari emiten yang mempunyai nilai transaksi tinggi dan merupakan saham saham yang sangat di cari sehingga lebih mampu menggambarkan aktivitas yang terjadi di pasar modal.

Terdapat banyak hal yang bisa mempengaruhi pergerakan harga saham pada pasar bursa. Bukan saja kinerja finansial perusahaan dan faktor internal lain di dalam perusahaan namun faktor di luar perusahaan atau faktor eksternal. Beberapa faktor internal yang memiliki pengaruh signifikan adalah profitabilitas perusahaan, proporsi hutang dan deviden. Sedangkan faktor eksternal yang dapat mempengaruhi diantaranya keadaan makro ekonomi, kebijakan pemerintah baik fiskal maupun moneter, kondisi politik suatu negara, kondisi sosial dan bahkan kondisi politik regional dan internasional.

Pemilu yang di adakan pada April 2019, memunculkan polarisasi dan perpecahan yang luar biasa pada masyarakat. Perbedaan antar kelompok pendukung di pertajam dengan pemberitaan melalui media digital dan hoaks. Kerusuhan pada tanggal 22 dan 23 Mei semakin menunjukan bahwa perbedaan politik dalam pemilu bisa berkembang menjadi krisis yang lebih buruk. Beberapa penelitian terdahulu, mengelompokan peristiwa politik merupakan salah satu kondisi eksternal yang mampu mempengaruhi keputusan investasi dan pasar modal.

Data yang dirilis oleh Reiters (Reuters, 2018) menunjukan pergerakan IHSG dan rupiah pada periode setahun, terlihat bahwa tiga dari lima tahun politik berakhir 
dengan koreksi rupiah, yakni pada 2004, 2014, dan 2015 dapat dilihat pada tabel di bawah ini.

\begin{tabular}{|l|l|l|l|l|l|l|}
\hline \multirow{2}{*}{ Periode } & IHSG & Rupiah & \multicolumn{4}{|l|}{} \\
\cline { 2 - 6 } & Posisi & Perubahan & $\%$ & Posisi & $\begin{array}{l}\text { Perubaha } \\
\text { n }\end{array}$ & $\%$ \\
\hline 1999 & 676,92 & 278,88 & 70 & 7.100 & -900 & - \\
\hline 2004 & $\begin{array}{l}1.000,2 \\
3\end{array}$ & 308,34 & 44.6 & 9.270 & 850 & 11.25 \\
\hline 2009 & $\begin{array}{l}2.534,3 \\
6\end{array}$ & $1.178,95$ & 86.98 & 9.404 & -1.716 & -15.4 \\
\hline 2014 & $\begin{array}{l}5.226,9 \\
5\end{array}$ & 952,77 & 22.29 & 12.388 & 217 & 1.8 \\
\hline 2015 & $\begin{array}{l}4.593,0 \\
1\end{array}$ & $-663,94$ & 12.13 & 13.788 & 1.400 & 11.3 \\
\hline
\end{tabular}

Sumber : data sekunder diolah, 2019

Tabel di atas menunjukkan bahwa pelaku pasar cenderung mengambil posisi cash out di tahun politik.Namun IHSG justru menunjukkan tren sebaliknya. Trader saham terlihat kurang mempedulikan risiko politik dengan tetap membukukan aksi beli, sehingga bursa saham menguat. Koreksi IHSG hanya terjadi pada 2015 ketika Indonesia menggelar pilkada serentak.

Pada Bursa Efek Indonesia, pemilu pada bulan April 2019 menunjukan pengaruh sejak awal tahun, di tunjukan dengan perlambatan perdagangan saham pada kuartal pertama tahun 2019 namun, sehari setelah pengumuman quick count terjadi penguatan IHSG dan kembali mengalami perlambatan pada saat kerusuhan 22 dan 23 Mei. Penelitian ini bertujuan untuk mengetahui pergerakan nilai saham sebelum pemilu April 2019, selama proses pemilu sampai dengan setelah proses pemilu.

\section{TINJAUAN PUSTAKA}

Informasi yang valid merupakan hal utama yang diperlukan dalam pengambilan keputusan di pasar modal. Salah satu teori yang mengacu pada respon harga saham terhadap informasi adalah Teori Hipotesis Pasar Efisien, Efisiensi pasar modal di tinjau dari kecepatan harga saham mencerminkan seluruh informasi yang tersedia di pasar. Pasar modal yang efisien adalah pasar modal yang harga sahamnya mencerminkan semua informasi yang relevan (Fama, 1973). Efisiensi pasar diuji dengan melihat return yang tidak normal. Pasar dikatakan tidak efisien jika terjadi abnormal return dalam jangka waktu yang cukup lama.

Teori lain mengemukakan bahwa pasar yang efisien tidak mungkin terjadi karena harga saham tidak mungkin mencerminkan semua informasi yang ada karena ada biaya abitrasi yang mahal untuk mendapatkan informasi (Stigliz, 1980). Informasi yang informative memungkinkan terjadinya perubahan keputusan pada investor 
sehingga mampu merubah harga saham melalui perubahan penawaran dan pembelian.

Informasi yang muncul dari suatu peristiwa dapat dipelajari pengaruhnya terhadap harga saham melalui studi peristiwa (event study). Studi peristiwa merupakan pengujian terhadap kecepatan penyesuaian harga terhadap informasi publik. Hal ini akan di ukur dari abnormal return yang terjadi. Abnormal return merupakan kelebihan dari return yang sesungguhnya dengan return yang diharapkan (Jogiyanto, 2015).

Dalam Signaling Theory (Jogiyanto, 2009) di jelaskan bahwa informasi yang di publikasikan akan memberikan signal bagi investor dalam pengambilan keputusan investasi.. Jika informasi yang di publikasi tersebut mengandung nilai positif, maka di harapkan pasar akan bereaksi positif pada saat pengumuman/publikasi tersebut di terima oleh pasar. Reaksi pasar di tunjukan dengan perubahan volume perdagangan saham. Jika investor menerima informasi tersebut secara optimis maka akan melakukan reaksi positif berupa kenaikan pembelian saham sebaliknya jika investor pesimis terhadap informasi yang di terima maka akan di respon secara negative yaitu dengan mengurangi pembelian saham dan akan menambah penawaran di pasar saham.

Reaksi investor terhadap informasi yang di perlihatkan dalam aksi jual dan beli saham selanjutnya akan mempengaruhi return saham. Euduardus (2001) menyatakan bahwa return merupakan tingkat keuntungan investasi. Return di bedakan ke dalam return yang di harapkan (expected return) dan return yang terjadi (realized return). Dalam penelitian ini, return akan di lihat pada Indeks LQ45, yaitu jenis indeks harga saham yang menggunakan emiten yang terdaftar pada kelompok LQ 45 di BEI sebagai komponen penghitungan indeks.

Kerangka berpikir dari penelitian ini dapat di gambarkan sebagai berikut:

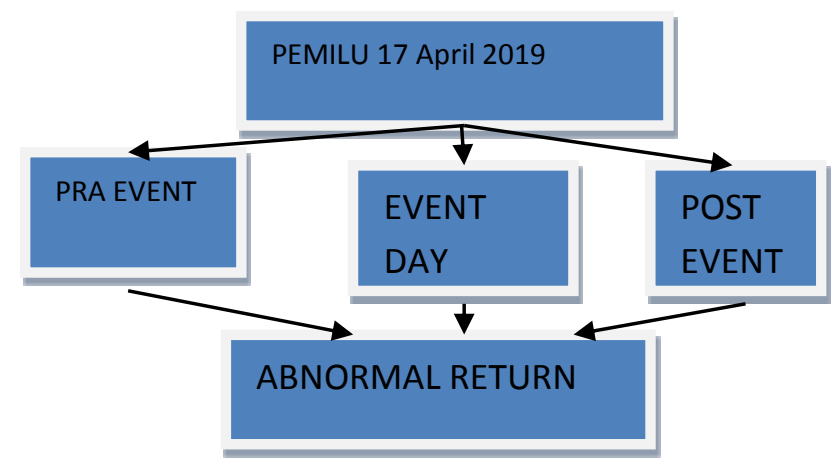

Penelitian berkaitan dengan situasi politik dan nilai saham pernah di lakukan beberapa peneliti lain, dan dapat dilihat pada tabel di bawah ini: 


\begin{tabular}{|l|l|}
\hline Judul dan Pengarang & Hasil Penelitian \\
\hline $\begin{array}{l}\text { Pengaruh Peristiwa Politik } \\
\text { (Pemilu Presiden dan }\end{array}$ & $\begin{array}{l}\text { Terdapat abnormal return di seputar } \\
\text { peristiwa politik nasional, namun tidak ada } \\
\text { Pengumuman Susunan } \\
\text { Kabinet) Terhadap Saham } \\
\text { Sektor Industri Di Bursa Efek } \\
\text { Indonesia } \\
\text { ( Katti, 2018) }\end{array}$ \\
\hline $\begin{array}{l}\text { Dampak Rumor Terhadap } \\
\text { Volatilitas Harga Saham } \\
\text { (Rijanto, 2011) }\end{array}$ & $\begin{array}{l}\text { Terdapat perubahan pola volatilitas yang } \\
\text { berbeda untuk tiap jenis saham yang } \\
\text { berbeda. Sehingga dampak rumor terhadap } \\
\text { tiap kelompok saham akan berbeda }\end{array}$ \\
\hline $\begin{array}{l}\text { Pengaruh Peristiwa Politik } \\
\text { terhadap Perubahan Harga } \\
\text { Saham } \\
\text { (Trisnawati, 2011) }\end{array}$ & $\begin{array}{l}\text { Tidak terdapat perbedaan abnormal return } \\
\text { antara sebelum dan sesudah pemilihan } \\
\text { presiden tahun 2004, terdapat perbedaan } \\
\text { abnormal return antara sebelum dan sesudah } \\
\text { pemiluhan presiden tahun 2009 }\end{array}$ \\
\hline
\end{tabular}

Dari kerangka berpikir dan telaah teori di atas, maka hipotesis penelitian di rumuskan sebagai berikut:

H1 : terdapat abnormal return yang significant antara sebelum, selama, dan sesudah pemilu 17 April 2019.

$\mathrm{H} 2$ : terdapat perbedaan abnormal return antara sebelum, selama, dan sesudah pemilu 17 April 2019.

\section{METODE PENELITIAN}

Penelitian ini merupakan penelitian kuantitatif dengan pendekatan studi peristiwa. Pendekatan ini di gunakan karena terdapat pengamatan pergerakan harga saham sebelum sebuah event/peristiwa terjadi, saat peristiwa terjadi dan setelah peristiwa terjadi.

Data yang dipergunakan adalah data sekunder yang bersumber dari www.idx.co.id dan yahoo finance. Data tersebut adalah Indeks LQ45 yang tercatat pada BEI. Rentang waktu pengamatan yaitu, 10 hari sebelum pemilu, satu hari pada saat pemilu dan 10 hari setelah pemilu. Yaitu 4 April sampai dengan 17 April 2019 untuk data sebelum peristiwa politik, 18 April 2019 untuk data saat peristiwa terjadi dan 19 April sampai dengan 2 Mei untuk data setelah peristiwa terjadi. Jangka waktu pengamatan di gambarkan sebagai berikut:

Tabel 1. Jangka Waktu Pengamatan

\begin{tabular}{|l|l|l|}
\hline Pra-event & Event & Post event \\
\hline $\begin{array}{l}4 \text { April }-17 \\
\text { April } \\
(10 \text { hari })\end{array}$ & 18 April & $\begin{array}{l}19 \text { April }-2 \\
\text { Mei (10 hari) }\end{array}$ \\
\hline
\end{tabular}


Populasi adalah seluruh emiten yang tercatat di Bursa Efek Jakarta yaitu sejumlah 627 perusahaan. Sampel yang di gunakan sebesar 45 perusahaan yang berada dalam kelompok LQ 45. Kelompok perusahaan ini di pilih karena 45 perusahaan ini merupakan perusahaan yang paling aktif dalam perdagangan saham. Tekhnik pengambilan sampel menggunakan Purposive Sampling dengan kriteria sebagai berikut: (1) tersedianya data selama periode pengamatan, (2) perusahaan tidak sedang melakukan company event. Dari hasil penyaringan terdapat 6 perusahaan yang melakukan company event sehingga di keluarkan dari daftar sample. Sehingga ada 39 perusahaan yang kemudian menjadi sampel.

Metode analisis data dilakukan dalam beberapa tahap yaitu:

A. Tahapan pertama, menghitung abnormal return dengan langkah sebagai berikut:

1. Menghitung rate of return saham individual $\left(\mathrm{R}_{\mathrm{it}}\right)$ selama waktu pengamatan dengan menggunakan rumus:

$$
\mathrm{R}_{\mathrm{it}}=\frac{\mathrm{P}_{\mathrm{it}}-\mathrm{P}_{\mathrm{it}-1}}{\mathrm{P}_{\mathrm{it}-1}}
$$

Keterangan :

$\mathrm{R}_{\text {it }}=$ return saham perusahaan $\mathrm{i}$ pada periode $\mathrm{t}$

$\mathrm{P}_{\mathrm{it}}=$ harga saham i pada waktu $\mathrm{t}$

$\mathrm{P}_{\text {it-t }}=$ harga saham I pada waktu t-1

2. Menghitung rate of return market $\left(\mathrm{R}_{\mathrm{mt}}\right)$ selama waktu pengamatan dengan menggunakan rumus:

$$
\mathbf{R}_{\mathrm{m}, \mathrm{t}}=\frac{\text { IHSG }_{\mathrm{t}}-\mathbf{I H S G}_{\mathrm{t}-\mathbf{1}}}{\text { IHSG }_{\mathrm{t}-1}}
$$

3. Menghitung expected return menggunakan market adjusted model Model ini menganggap bahwa penduga yang terbaik untuk mengestimasi return suatu sekuritas adalah return indeks pasar pada saat tersebut. Return tidak normal masing-masing sekuritas yang menggunakan model disesuaikan pasar dapat dihitung dengan mengurangkan return yang terjadi untuk masing-masing sekuritas dengan return indeks pasar pada hari yang sama.

4. Menghitung abnormal return yang merupakan selisih antara return sesungguhnya dengan return yang diharapkan dengan menggunakan rumus:

$$
\mathbf{A R}_{\mathrm{it}}=\mathbf{R}_{\mathrm{it}}-\mathbf{E}\left(\mathbf{R}_{\mathrm{it}}\right)
$$

\section{Keterangan :}

$\mathrm{AR}=$ abnormal returnSekuritas 1 pada periode $\mathrm{t}$

$\mathrm{R}_{\mathrm{iJ}} \quad=$ return realisasi sekuritas ke-i pada periode $\mathrm{t}$

$\mathrm{E}\left(\mathrm{R}_{\mathrm{it}}\right)=$ Expected return sekuritas I pada periode $\mathrm{t}$ 
5. Menghitung rata-rata abnormal return dengan rumus :

$$
A A R t=\frac{\sum_{i=1}^{n} \text { ARi.t }}{n}
$$

B. Tahapan kedua, melakukan uji hipotesis dengan melakukan uji t untuk hipotesis pertama, yaitu menguji apakah ada abnormal return selama periode pengamatan, dan uji anova untuk mengetahui Apakah terdapat beda rata rata abnormal return sebelum peristiwa pemilu, pada saat pemilu dan sesudah pemilu.

\section{HASIL PENELITIAN DAN PEMBAHASAN \\ Analisa Deskriptif}

Rata - rata abnormal return selama10 hari sebelum event, selama event dan 10 hari setelah event dari 39 perusahaan yang termasuk ke dalam sampel dapat dilihat pada tabel di bawah ini:

\section{Tabel 2}

\section{Rata-rata Abnormal Return Selama Hari Pengamatan}

\begin{tabular}{|l|c|l|l|l|l|}
\hline Day & AAR & Day & AAR & Day & AAR \\
\hline H-10 & $-0,0036$ & Event & - & H+10 & $-0,0004$ \\
& & & 0,0032 & & \\
\hline H-0 & 0,0018 & & & $\mathrm{H}+0$ & 0,0010 \\
\hline H-8 & $-0,0080$ & & & $\mathrm{H}+8$ & 0,0071 \\
\hline H-7 & 0,0087 & & & $\mathrm{H}+7$ & 0,0041 \\
\hline H-6 & & & & $\mathrm{H}+6$ & \\
& $-0,0032$ & & & & $-0,0011$ \\
\hline H-5 & 0,0080 & & & $\mathrm{H}+5$ & 0,0013 \\
\hline H-4 & $-0,0020$ & & & $\mathrm{H}+4$ & 0,0042 \\
\hline H-3 & & & & $\mathrm{H}+3$ & \\
& 0,0000 & & & & $-0,0036$ \\
\hline H-2 & & & & $\mathrm{H}+2$ & \\
& 0,0054 & & & & $-0,0012$ \\
\hline H-1 & & & & $\mathrm{H}+1$ & \\
& $-0,0001$ & & & & $-0,0113$ \\
\hline
\end{tabular}

Sumber : data sekunder di olah, 2019

Jika rata rata abnormal return di kelompokkan ke dalam tiga event yaitu PraEvent, Event Day dan Post Event, maka rata rata abnormal return dapat dilihat pada tabel di bawah ini:

\begin{tabular}{|l|l|c|}
\hline Pra Event & Event & Post Event \\
\hline 0,000698 & $-0,0032$ & 0,000022 \\
& & \\
\hline
\end{tabular}

Sumber : data sekunder di olah, 2019 


\section{Uji Normalitas Data}

Sebelum dilakukan uji hipotesis dilakukan uji normalitas data terbih dahulu. Uji normalitas menggunakan One Sample Kolmogorov-Smirnof Test untuk sample dan Shapiro Walk. Hasil Analisis menunjukan data terdistribusi normal atau tidak. Jika data terdistribusi normal maka uji hipotesis bisa dilakukan dengan T-test dan anova. Hasil uji normalitas dapat dilihat pada tabel di bawah ini:

\section{Tabel 3. Hasil Uji Normalitas}

\begin{tabular}{|c|c|c|c|c|c|c|c|}
\hline & \multirow[t]{2}{*}{ Event } & \multicolumn{3}{|c|}{ Kolmogorov-Smirnov $^{\mathrm{a}}$} & \multicolumn{3}{|c|}{ Shapiro-Wilk } \\
\hline & & Statistic & $\mathrm{df}$ & Sig. & Statistic & df & Sig. \\
\hline \multirow[t]{2}{*}{$\overline{\mathrm{AAR}}$} & $\begin{array}{l}\text { Pra_Ev } \\
\text { ent }\end{array}$ & .191 & 10 & $.200^{*}$ & .953 & 10 & .702 \\
\hline & $\begin{array}{l}\text { Post_E } \\
\text { vent }\end{array}$ & .260 & 10 & .053 & .930 & 10 & .450 \\
\hline
\end{tabular}

Tabel di atas menunjukkan hasil uji Shapiro Wilk dan Lilliefors. Nilai p value (Sig) lilliefors 0,200 pada kelompok Pra Event dan 0.053 pada kelompok Post event, kedua nilai $\mathrm{p}$ value $>0,05$ maka berdasarkan uji lilliefors, data tiap kelompok berdistribusi normal.

P value uji Shapiro Walk pada kelompok Pra Event sebesar 0,702>0,05 dan pada kelompok Post Event sebesar 0,45>0,05. Karena semua nilai $\mathrm{p}>0,05$ maka kedua kelompok sama-sama berdistribusi normal berdasarkan uji Shapiro Walk.

\section{Uji Homogenitas Data}

Uji homogenitas adalah pengujian mengenai sama tidaknya variansi-variansi dua data distribusi atau lebih, digunakan pada uji parametris yang menguji perbedaan antara kedua kelompok atau beberapa kelompok yang berbeda subjeknya atau sumber datanya sehingga uji compare means dengan t-test dan anova dapat dilakukan. Hasil Uji homogenitas dapat dilihat pada tabel di bawah ini:

\section{Tabel 4. Uji Homogenitas}

\begin{tabular}{|c|c|c|c|}
\hline Levene Statistic & df1 & df2 & Sig. \\
\hline $.229^{\mathrm{a}}$ & 1 & 18 & .638 \\
\hline
\end{tabular}

Tabel di atas menunjukkan hasil uji homogenitas dengan metode Levene's Test. Nilai Levene ditunjukkan pada baris nilai based on Mean, yaitu 1,236 dengan $\mathrm{p}$ value (sig) sebesar 0,281 di mana $\mathrm{p}>0,05$ yang berarti terdapat kesamaan varians antar kelompok atau yang berarti homogen.

Hasil uji normalitas dan homogenitas menunjukan bahwa data terdistribusi normal sehingga dapat dilakukan uji parametric. Untuk Hipotesis pertama dilakukan dengan t-test sedangkan pada hipotesis kedua dilakukan dengan Anova. 


\section{Hasil Uji T-Test}

\section{Tabel. 5}

Hasil Uji T-Test

\begin{tabular}{|c|c|c|c|c|c|}
\hline Day & AAR & $\mathbf{R M}$ & T Test & T tabel & Sig \\
\hline H-10 & $\begin{array}{l}- \\
0.0036\end{array}$ & 0.0061 & $\begin{array}{l}- \\
0.7132\end{array}$ & 2.079614 & No \\
\hline H-9 & 0.0018 & $\overline{-}-\overline{0}(0046$ & 0.3554 & 2.079614 & No \\
\hline H-8 & $\begin{array}{l}- \\
0.0080\end{array}$ & $\begin{array}{l}- \\
0.0059\end{array}$ & $\begin{array}{l} \\
1.5920 \\
\end{array}$ & 2.079614 & No \\
\hline $\mathrm{H}-7$ & 0.0087 & 0.0089 & 1.7273 & 2.079614 & No \\
\hline H-6 & $\overline{-}-0032$ & $\begin{array}{l}- \\
0.0002\end{array}$ & $\begin{array}{l}- \\
0.6264\end{array}$ & 2.079614 & No \\
\hline H-5 & 0.0080 & $\begin{array}{l}- \\
0.0158\end{array}$ & 1.5929 & 2.079614 & No \\
\hline $\mathrm{H}-4$ & $\begin{array}{l}- \\
0.0020\end{array}$ & 0.0005 & $\begin{array}{l}-4025 \\
0.45\end{array}$ & 2.079614 & No \\
\hline H-3 & 0.0000 & 0.0048 & $\begin{array}{l}- \\
0.0027\end{array}$ & 2.079614 & No \\
\hline $\mathrm{H}-2$ & 0.0054 & 0.0048 & 1.0617 & 2.079614 & No \\
\hline $\mathrm{H}-1$ & $\begin{array}{l}- \\
0.0001\end{array}$ & 0.0000 & $\begin{array}{l}- \\
0.0150\end{array}$ & 2.079614 & No \\
\hline H0 & $\begin{array}{l}- \\
0.0032\end{array}$ & 0.0060 & $\begin{array}{l}- \\
0.6420\end{array}$ & 2.079614 & No \\
\hline $\mathrm{H}+1$ & $\begin{array}{l}- \\
0.0004\end{array}$ & 0.0000 & $\begin{array}{l} \\
0.0779\end{array}$ & 2.079614 & No \\
\hline $\mathrm{H}+2$ & 0.0010 & $\overline{-}-0.0170$ & 0.2059 & 2.079614 & No \\
\hline $\mathrm{H}+3$ & 0.0071 & 0.0098 & 1.4119 & 2.079614 & No \\
\hline $\mathrm{H}+4$ & 0.0041 & $-\bar{l}-0023$ & 0.8165 & 2.079614 & No \\
\hline $\mathrm{H}+5$ & $\begin{array}{l} \\
0.0011\end{array}$ & $\begin{array}{l}- \\
0.0148\end{array}$ & $\begin{array}{l}- \\
0.2100\end{array}$ & 2.079614 & No \\
\hline $\mathrm{H}+6$ & 0.0013 & 0.0056 & 0.2643 & 2.079614 & No \\
\hline $\mathrm{H}+7$ & 0.0042 & 0.0028 & 0.8255 & 2.079614 & No \\
\hline $\mathrm{H}+8$ & $\begin{array}{l}- \\
0.0036\end{array}$ & 0.0058 & $\begin{array}{l}- \\
0.7149\end{array}$ & 2.079614 & No \\
\hline $\mathrm{H}+9$ & $\begin{array}{l}- \\
0.0012 \\
\end{array}$ & 0.0000 & $\begin{array}{l} \\
0.2301 \\
\end{array}$ & 2.079614 & No \\
\hline $\mathrm{H}+10$ & $\begin{array}{l} \\
0.0113\end{array}$ & $\overline{-}-0121$ & $-\overline{2.2473}$ & 2.079614 & No \\
\hline
\end{tabular}

Sumber: Data sekunder di olah, 2019

Dari hasil uji T-Test di ketahui bahwa selama periode pengamatan nilai $\mathrm{T}$ hitung lebih kecil dari nilai $\mathrm{T}$ tabel, $\mathrm{T}$ hitung $<\mathrm{T}$ Table, sehingga hipotesis pertama tidak terbukti atau tidak ada abnormal return yang significant pada periode 10 hari sebelum peristiwa, pada saat peristiwa dan 10 hari setelah peristiwa. 
Hasil uji statistik ini menunjukan bahwa trader saham kurang mempedulikan risiko politik domestik dengan tetap membukukan aksi beli. Hal ini konsisten dengan laporan penelitian yang diterbitkan oleh Reiters (Reuters, 2018) bahwa indeks harga saham tidak terpengaruh pada saat pemilu tahun 1999, 2004, 2009 dan 2014. Indeks terpengaruh justru pada saat pilkada serentak pertama kali di adakan pada 2015. Investor lebih terpengaruh oleh sentiment global seperti perang dagang antara Amerika dan Tingkopk serta kebijakan dari The Federal Reserved.

Pada $\mathrm{H}-1$ sampai $\mathrm{H}+1$ memang terlihat pergerakan negatif indeks harga saham tetapi segera di respon positif oleh pasar pada $\mathrm{H}+2$, hal ini di karenakan pasar percaya bahwa pelaksanaan pemilu yang aman dan hasil quick count yang menunjukan terpilihnya kembali petahana tidak akan memberikan perubahan besar pada kebijakan politik dan ekonomi dalam negeri.

\section{Hasil Uji ANOVA}

Tabel 6

Hasil Uji Anova

\begin{tabular}{|c|c|c|c|c|c|}
\hline & \begin{tabular}{|l|} 
Sum of \\
Squares
\end{tabular} & df & \begin{tabular}{|l|} 
Mean \\
Square
\end{tabular} & $\mathrm{F}$ & Sig. \\
\hline $\begin{array}{l}\text { Between } \\
\text { Groups } \\
\text { Within } \\
\text { Groups } \\
\text { Total }\end{array}$ & $\begin{array}{l}.000 \\
.000 \\
.001\end{array}$ & $\begin{array}{r}2 \\
18 \\
20\end{array}$ & $\begin{array}{l}.000 \\
.000\end{array}$ & .265 & .770 \\
\hline
\end{tabular}

Dilihat dari hasil uji memakai ANOVA, diketahui bahwa p value lebih besar dari degree of freedom, atau $0,770>0.05$ sehingga secara statistik dapat di katakan bahwa tidak ada perbedaan abnormal return saham pada kelompok saham LQ 45 pada sebelum pilpres 2019, saat pilpres 2019 dan setelah Pilpres 2019. Hal ini konsisten dengan hipotesis pertama yang menunjukan tidak terdapat abnormal return yang signifikan selama periode pengamatan.

Respon pasar terhadap kondisi politik dalam negeri cenderung stabil dan tetap sehingga harga sahan tidak terpengaruh. Walaupun sempat terjadi penurunan harga saham pada $\mathrm{H}-1, \mathrm{H} 0$ dan $\mathrm{H}+1$, namun segera di respon positif pada $\mathrm{H}+2$. Trend penurunan kembali terjadi pada $\mathrm{H}+8$ sampai $\mathrm{H}+10$ dikarenakan perang opini di media social anatar pihak pihak yang berperkara dalam pemilu. Namun terjadinya trend negative ini tidak cukup signifikan sehingga indeks harga saham kembali terkoreksi positif.

\section{KESIMPULAN DAN SARAN \\ Kesimpulan}

Berdasarkan hasil uji statistik dapat di ambil kesimpulan:

1. Tidak terjadi Abnormal Return yang signifikan selama periode pengamatan yaitu 10 hari sebelum peristiwa, pada saat peristiwa dan 10 hari setelah peristiwa atau total 21 hari. 
2. Tidak terdapat perbedaan abnormal return antara ketiga periode pengamatan yaitu 10 hari sebelum peristiwa, pada saat peristiwa dan 10 hari setelah peristiwa.

3. Peritiwa politik di Indonesia yaitu pemilu yang pada 17 April 2019, tidak memberikan dampak yang signifikan pada harga saham. Pasar memiliki kepercayaan bahwa pemilu akan berjalan dengan baik dan lancar serta tidak akan terjadi gejolak ekonomi dan politik sehingga investor tidak melakukan aksi jual yang berlebihan.

4. Investor cenderung menahan diri/wait and see terhadap kondisi ekonomi dan politik hal ini di tunjukan dengan indeks yang tetap stabil, kalaupun terjadi trend negative dalam beberapa hari akan kembali terkoreksi positif.

\section{Saran}

Penelitian ini juga memiliki beberapa keterbatasan, oleh karena itu peneliti memberikan saran untuk penelitian lebih lanjut yaitu:

1. Menggunakan sample lebih banyak, tidak hanya terbatas pada perusahaan yang berada dalam kelompok LQ45

2. Penelitian ini mengunakan market adjusted model untuk menghitung expected return. Disarankan, penghitungan expected return dilakukan memakai market model dengan menggunakan periode estimate event yang lebih lama, sehingga trend perubahan harga saham bisa di ketahui.

3. Penelitian ini juga tidak melibatkan variable volume perdagangan dan variable lain yang bisa saja dipengaruhi oleh peristiwa politik yang terjadi.

\section{DAFTAR PUSTAKA}

Fama, E.F \& Macbeth, J.D., 2073. Risk, Return and Equilibrium: Empirical test. Journal of Political Economy. Vol. 81. No.03. The University of Chicago Press

Hartono, Jogiyanto,. 2015. Teori Portofolio dan Analisis Investasi. Edidi kesepuluh. Yogyakarta: BPFE

Katti, S.W.B., 2012. Pengaruh Peristiwa Politik (pemilu Presiden dan Pengumuman Susunan Kabinet) terhadap Saham Sektor Industri Di Bursa Efek Indonesia. Jurnal Manajemen. Vol. 01 No. 01. Universitas Merdeka Madium.

Murdifi dkk., 2018. Efen Peristiwa Politik Terhadap Kinerja Pasar Modal Indonesia (Even Study pada vonis Yang Diberikan kepada basuki Tjahaja Purnama). E-JRA Journal. Vol. 07. Fakultas Ekonomi dan Bisnis Universitas Islam Malang.

Rijanto, Y.A. 2011. Dampak Rumor Terhadap Volatilitas Harga Saham. Jurnal managemen Bisnis. Vol. 3 No. 3. Prasetiya Mulya Business School Jakarta 
Stiglizt, J.E \& Grossman, S.F. 1980. On the Impossibility of Informationally Efficient Markets. The American Economic Review. Vol. 17 No.3. American Economic Association.

Tandelilin, E. 2010. Analisis Investasi dan Manajemen Portofolio. BPFE. Yogykarta

Trisnawati, N.K.D., \& Ni N.A.D., 2013. Analisis pengaruh reshuffle Kabinet Indonesia bersatu Terhadap Harga Saham LQ45 di Bursa Efek Indonesia. EJurnal manajemen Universitas Udayana. Vol. 2 No. 10. Universitas Udayana, Denpasar Bali 